\title{
St Johns Park
}

\section{Vicki Movizio}

The suburb of St Johns Park was part of the traditional land of the Cabrogal people, a subgroup of the Gandangarra clan. They are thought to have lived on the lands that stretched between what became the Fairfield district and the Liverpool area for more than 30,000 years. The heavily wooded land provided the shelter of gums, silver oaks and swamp oaks, along with a ready source of fresh water and fish, eels and shellfish in local waterways, including Clear Paddock Creek.

St Johns Park is now a suburb of Fairfield City, situated 35 kilometres west of Sydney. It is named after the Old Parish of St John in which it is located. When Liverpool was established in 1810, St Johns Park was within the Liverpool boundaries. In 1892 it became a district of the Municipality of Cabramatta and Canley Vale, and finally a part of Fairfield Municipal Council area upon its merger with Cabramatta and Canley Vale Council in 1948. The suburb is bounded by Smithfield Road, Canley Vale Road, Humphreys Road and Edensor Road (formerly Parkes Road).

\section{Early settlement}

St Johns Park was first sighted by Europeans on 27 April 1788 from the high vantage point of Prospect Hill. ${ }^{1}$ The area was included in the 12,300-acre (4978-hectare) Orphan School land grant of 1803, set up by Governor King to provide training and accommodation for orphans in the early Sydney settlement. The large estate was intended to supply produce for the Orphan Schools. The idea was presumably to lease parcels of the land to landholders. Initially there were not too many offers. Nathaniel George Bull, an early political figure of note in the area, purchased many of the blocks. Reverend Robert Cartwright was also an early landholder. A gazetteer of 1848 shows 'St Johns Farm' located at the centre of the suburb. ${ }^{2}$

\section{Development and infrastructure}

A witness to the commission investigating railway sites in 1916 described the area as follows:

...The whole of St Johns Park...is good land, suitable for agriculture. In St Johns Ward, there are 112 holdings, comprising $11751 / 4$ acres. There are 900 acres not yet cut up, suitable for poultry farms. There are several other holdings in the district from 50 to 200 acres. There were $441 / 4$ acres under grapes last year, which produced 9024 cases, equal to 117 tons. We also produced 1000 gallons of wine. There are 117 acres under stone fruit, one half being young plants, which produced 5000 cases, and last year was a comparatively bad one. Of poultry, which is the main industry of our district there were 14,495 which produced 14,000 eggs. There are in the district 95 beehives, which produced 2 tons, 6 cwt of honey. We also have cattle and horses. An area there of 900 acres is used as a sort of rest paddock. It is splendid country. The population on the 113 holdings is 276 males and 154 females. There are 430 adults, and of children, there are seventy seven boys and seventy two girls. ${ }^{3}$ 
By 1891 a public school had been established on Parkes Road (now Edensor Road) to cater to the growing number of children in the community. The first teacher was Mr Thomas Dibden.

Another indication of the growth of St Johns Park was that it had its own post office which was opened in April 1888. The first postmaster was Mr John Henry Pope. Electricity came relatively late to the area under the direction of Mr P Powditch, Electrical Engineer for Cabramatta and Canley Vale Council in $1937 .{ }^{4}$

Some other infrastructure was also slow to come to the area. There were difficulties in attending St Johns Anglican church on Sundays in wet weather, as the dirt roads turned to mud and much of the congregation came on foot. The local bus service had to detour to individually pick up the wedding guests of Mr and Mrs Wilde Spence as it had rained heavily for three weeks. ${ }^{5}$ When road building finally commenced, materials were obtained from St Johns Park's Road Metal Quarry.

\section{Italian heritage}

A major reason for the expansion of the area was that a number of European migrants, mainly Italians, had settled in St Johns Park. Members of the Bellotti and Gava families who had survived the ill-fated expedition of the Marquis de Rays to Port Breton, New Ireland, arrived in Sydney in $1881 .^{6}$ Along with other survivors, they were given permission to settle in New South Wales by Sir Henry Parkes. After serving a six-month indentured period to repay the New South Wales government for their rescue, many of the Italians headed north to New Italy near Lismore. Widower Domenico Bellotti remained in Sydney and married Santa Maria Gava, whose husband had died while at Port Breton in New Ireland. They purchased land on Bulls Road and established a vineyard and licensed wine cellar. ${ }^{7}$

Francesco Gava, son of Santa Maria, was eight years old when he arrived in Australia with his mother and four siblings. He went on to become the licensee of the vineyard after his mother's death in 1901, as well as becoming the local council's overseer of roads in 1906. He also took over the role of postmaster at St Johns Park in the late 1920s. He and his wife Palmira Marantelli (also from northern Italy) had one son and five daughters, all of whom worked for some time in the vineyard and the Post Office which was built onto the end of their house on Bulls Road. Francesco Gava donated land to extend the local park which is now known as St Johns Park Reserve. ${ }^{8}$ The park is still used today for a variety of sports, including tennis and cricket.

\section{Migration and multiculturalism}

The first Yugoslav migrants to the area are believed to be Theodore and Samuel Seravich who arrived in 1885. In 1893, Theodore purchased 10 acres (4 hectares) between Bulls Road and Burns Road, St Johns Park as well as an adjoining property. ${ }^{9}$ He also cultivated wine grapes. A 
bridge crossing Clear Paddock Creek, on Canley Vale Road near the site of his farm, was named in his memory in 2004. There are still members of both the Gava and Seravich families living in the local area.

There was a further influx of migrants in the late 1940s. Families once again came from southern Europe and names such as Portalesi, Gerichiand and Di Biasi became familiar. Relics of the early European farmers are still to be found in the area with wild fennel and chicory growing along the banks of Clear Paddock Creek.

The community of St Johns Park had an active social calendar. There was an annual agricultural show held each year. Social functions were organised through involvement in the local public school and St Johns Park Progress Society. Fund raising events included musical evenings, dances and euchre card nights. St John's Anglican church was often the venue for concerts. The church also held an annual Harvest Festival.

Today the population of St Johns Park reflects the multicultural makeup of the whole of the Fairfield area's community. This is particularly evident when looking at the local places of worship, clubs and restaurants. Around 54 per cent of the residents have non-English speaking backgrounds. The area's present day population still reflects early European migration. There has been a shifting demography in recent years with many new residents from Asia and the Middle East now residing in St Johns Park. ${ }^{10}$ The population of this suburb is a reminder that 133 countries are represented within Fairfield City Council's boundaries, with over 70 languages spoken. In St Johns Park, around 80 per cent of residents speak a second language. ABS figures show that there is also a lower rate of unemployment in the area than in the Fairfield City Council area as a whole.

\section{Building community institutions}

St John's Anglican church was originally built and dedicated on Humphreys Road in 1915 on land donated by Mr McMachern, and then later dismantled and rebuilt on its present site on Edensor Road in 1925. ${ }^{11}$ The Vietnamese Evangelical church holds services every Sunday at St John's Anglican church. The Buddhist Phap Bao Temple is also on Edensor Road. The Bible Baptist church is located on the corner of Edensor and Humphries roads. There is also the St Nikola Tavelic Croatian Catholic church located at 121 Brisbane Road, adjoining the Cardinal Stepinac Retirement Village.

St Johns Park Bowling Club, Edensor Road, adjoins the Park where Bibbys Road was formerly located and opened in 1954. The membership of the club now exceeds 20,000. National bowls championships are often telecast from its state-of-the-art greens. St Johns Park Sports Club (Jadran Hajduk Croatian Club) is on Edensor Road opposite the park. 
Nowadays most of the land in St Johns Park has been developed. The median house price in the first quarter of 2011 was $\$ 475,000$. Transport in the area is serviced by Westbus who bought out the family-operated Calabro Brothers bus company in the late 1980s. There is access to the Liverpool-Parramatta Tway at the St Johns bus stop.

St Johns Park has its own public high school on Mimosa Road. It was opened in 1978 and is used on Saturdays for Assyrian and Chinese language classes for children.

Clear Paddock Creek, St Johns Park, was chosen as the first site of Fairfield City Council's 'Restoring the Waters' project in 2001. ${ }^{12}$ A 500-metre section of the creek that crosses the suburb was restored from a concrete channel back to a 'living stream'. The project earned the council an international environmental award.

Vicki Movizio is a local studies librarian and historian with a keen interest in the history of south-western Sydney

\section{References}

Council of Municipality of Fairfield, Municipality of Fairfield, Record of Progress, Fairfield Municipal Council, Fairfield, 1959

Beverley Donald, Foundations of Faith: Christian Churches in the Fairfield Area, Fairfield City Council, Fairfield, 2005

A Geikie, Fairfield through the Centuries, Council of the Municipality of Fairfield, Fairfield, 1949

Vance George, Fairfield: a History of the District, 2nd edition, Fairfield City Council, Fairfield, 1991

Vicki Movizio, 'The Gava Family in Australia', unpublished research paper for Centre for Local History, University of New South Wales, 1994

Brenda Pittard, (compiler), Fairfield, a pictorial history, Fairfield City Council, Wakeley, 1990

'5 Creeks Share a Vision', Fairfield City Council pamphlet, available online at www.fairfieldcity.nsw.gov.au/upload/jfcrs43521/FCC_5creeks_LORES.pdf viewed 20 July 2011

'Our Club History', St Johns Park Bowling Club website, Bowls section, http://www.sjpbowling.com.au, viewed 10 April 2011

'St Johns Park', Fairfield City Council website, Suburbs section, http://www.fairfieldcity.nsw.gov.au, viewed 12 June 2008 
Anne-Gabrielle Thompson, Turmoil - Tragedy to Triumph: the story of New Italy, New Italy Centenary Committee, Queensland, 1980

Henry Thompson, Back to Cabramatta and Canley Vale Week, May 6-12, 1935, Souvenir Booklet and Official Programme, Cabramatta and Canley Cale Council, 1935

\section{Endnotes}

${ }^{1}$ Brenda Pittard (compiler), Fairfield, a pictorial history, Fairfield City Council, Wakeley, 1990, p 9

${ }^{2}$ William Henry Wells, Geographic Dictionary or Gazetteer of the Australian Colonies, W \& F Ford, Sydney, 1848

${ }^{3}$ Vance George, Fairfield: a History of the District, 2nd edition, Fairfield City Council, Fairfield, 1991, p 114

${ }^{4}$ Henry Thompson, Back to Cabramatta and Canley Vale Week, May 6-12, 1935, Souvenir Booklet and Official Programme, Cabramatta and Canley Vale Council, 1935

${ }^{5}$ Beverley Donald, Foundations of Faith: Christian Churches in the Fairfield Area, Fairfield City Council, Fairfield, 2005, p 59

${ }^{6}$ Anne-Gabrielle Thompson, Turmoil - Tragedy to Triumph: the story of New Italy, New Italy Centenary Committee, Queensland, 1980

${ }^{7}$ Vicki Movizio, 'The Gava Family in Australia', unpublished research paper for Centre for Local History, University of New South Wales, 1994

${ }^{8}$ Ron Wenban, grandson of Francesco Gava, 2002

${ }^{9}$ Vance George, Fairfield: a History of the District, 2nd edition, Fairfield City Council, Fairfield, 1991 p 212

${ }^{10}$ Fairfield City Council website, http://www.fairfieldcity.nsw.gov.au, viewed 26 July 2011

${ }^{11}$ Beverley Donald, Foundations of Faith: Christian Churches in the Fairfield Area, Fairfield City Council, Fairfield, 2005, p 58

12 '5 Creeks Share a Vision', Fairfield City Council pamphlet, available online at www.fairfieldcity.nsw.gov.au/upload/jfcrs43521/FCC_5creeks_LORES.pdf, viewed 20 July 2011 